Ewa Katarzyna Citko

University of Bialystok

DOI: 10.15290/rtk.2021.20.12

iD $0000-0002-7246-6921$

\title{
Transcendent Images and Semina Verbi in Carlos Reygadas' Films
}

This article is an analytical and interpretive reading of the Mexican film director Carlos Reygadas' work in light of "semina Verbi" (seeds of the Word). In his films, Reygadas explores the alienation and confusion that man, who has rejected traditional values and faith in God, experiences in the modern world. At the same time and like his characters, Reygadas seeks transcendence and the possibility of spiritual rebirth. His films are not strictly religious, but they do contain faint echoes the Gospel or semina Verbi, meaning "seeds of the Word" that are present in non-Christian cultures and secular works of art. As John Paul II said, the Spirit sows seeds of the Word in different rites and cultures that open them up to the fullness of meaning in Jesus Christ.

Viewers can find semina Verbi in different elements of Reygadas' films, including: the characters' motivations, aspirations, and actions; the symbolic structure of the film's space and time; and in the specific narrative style that invites viewers to meditate and contemplate. This Mexican director's films echo man's hidden longing for the spiritual world and for union with the sacred, with nature that surrounds him (which is "divinized" in many films), with himself, and with his spirituality that has been lost.

An essential element of Reygadas' work is the pursuit of transcendence understood in a specific way. The director does not seek metaphysical order in his works. Instead, he uncovers the biological and bodily dimensions of the world and recalls the eternal cycle of death and rebirth in nature. This is why transcendence often has a sexual dimension in Reygadas'films; his characters experience a renewed physical interaction by which they transcend themselves. This type of experience leads the characters from passivity, stagnation, and death to the vitality and life. Reygadas' characters' search for metaphysical and spiritual transcendence and their experience of bodily transcendence are motivated and characterized by something similar: the desire to transcend 
their own limitations and barriers-an experience of contact with the One Who surpasses man, or that which man surpasses.

The presence of images of transcendence and hidden semina Verbi are important determinants of Reygadas' creative works. The cinematic reality that he creates is a distant sign of a higher order established by something other than man, and, yet, it is an order over which man has an overwhelming influence.

Key words: film, transcendence, semina Verbi, Carlos Reygadas.

Theology of Culture

\section{„Religious films” and the works of Carlos Reygadas}

Is modern cinema interested in telling the story of God, religion, or the supernatural dimension of reality? Judging by the popularity of so-called "religious" films and the number of works that deal with broadly understood sacred themes (these phenomena mutually reinforce and influence each other) produced in recent years, one can answer affirmatively. The number of Polish film scholars interested in this subject has also increased, ${ }^{1}$ even though a deeper body of academic work has yet to be produced in this area due to the fact that it is difficult to arrive at a synthetic and uniform approach to this genre because this phenomenon is multidimensional and multithreaded.

The difficulty arises when one tries to define what a religious film is. Some researchers such as Marek Sokolowski ${ }^{2}$ claim that the religiousness of a film is determined by the issues that the film raises and the ways it presents them, and not by sacred themes and content. Others, however, like Mariola Marczak, ${ }^{3}$ have asserted that religious films follow certain rules. Tomasz Kłys ${ }^{4}$ mentions that there are three ways

$1 \quad$ For further information on this subject, see M. Marczak, Poetyka filmu religijnego (Kraków: 2000); I. Kolasińska, "Film biblijny," in Wokót kina gatunków, ed. K. Loska (Kraków: 2001); Poszukiwanie i degradowanie sacrum w kinie, eds. W. Przylipiak and K. Kornacki(Gdańsk:2002); M. Sokołowski, Kościót, kino, sacrum. W poszukiwaniu definicji filmów o tematyce religijnej (Olsztyn: 2002); T. Kłys, "Filmy (nie)religijne," in Między stowem a obrazem, eds. M. Jakubowska, T. Kłys, and B. Stolarska(Kraków:2005); Światowa encyklopediafilmu religijnego, eds. M. Lis and A. Garbicz (Kraków: 2007); M. Kempna-Pieniążek, Formuty duchowości w kinie najnowszym (Katowice: 2013); Sacrum w kinie dekadę później. Szkice, eseje, rozprawy, eds. S. J. Konefał, W. Zelent, and K. Kornacki (Gdańsk: 2013); Blask religii. Media w poszukiwaniu sacrum i autorytetów, ed. M. Sokołowski (Toruń: 2016).

M. Sokołowski, Kościót, kino, sacrum.

M. Marczak, Poetyka filmu religijnego.

T. Kłys, "Filmy (nie)religijne." 
that one can understand and differentiate the current phenomenon: firstly, religious films can be stories taken from Old and New Testament or hagiographies; secondly, religious films also include artistic works and expressions of film writers' religiosity or metaphysical interests; and thirdly, religious films can be "paradoxically religious," meaning they have a particular impact on viewers, who are inclined to classify these works as sacred because of the religious experiences and reflections they evoke. In her book on current cinematic expressions of spirituality, Magdalena Kempna-Pieniążek ${ }^{5}$ narrows the scope of religious cinema to those works that draw on the beliefs, worldviews, and religious symbols of those who follow specific religions. By deliberately defining the research field in this way, Kempna-Pieniążek is able to analyze specific expressions of spirituality in contemporary feature films.

Both Tomasz Kłys and Mariola Marczak highlight that definitions of a religious film should include the attitude of the viewer, whose disposition and religious competences determine whether or not the viewer will notice the film's sacred meaning. Magdalena Kempna-Pieniążek comes to similar conclusion:

The broad scope of the definitions of these trends usually boil down to the observation that every work from which it is possible to interpret additional meaning that directs the viewer's attention to the mystery of life, the meaning of existence or metaphysics is religious if the viewer views the film through the proper lens of the worldview and attitude of a specific spirituality. ${ }^{6}$

The authors of the World Encyclopedia of Religious Film ${ }^{7}$ include various categories that take into account the audience's attitude and fall within the broad definition of religious cinema, including the following feature, documentary, and animated films:

1. biblical-themed films, 2 . adaptations of literary works that are widely considered religious, 3 . hagiographies and biographies whose main characters are relevant to particular religions or denominations, 4 . films about people who have dedicated themselves to God and serving others; 5 . films whose creators struggle in different ways with the moral tenets of their faith, 6. films that contain hidden religious messages, themes, symbols, etc. that convey deeper spiritual or metaphysical meanings,

$5 \quad$ M. Kempna-Pieniążek, Formuty duchowości.

$6 \quad$ Ibid, 54

$7 \quad$ M. Lis, ed., Światowa encyklopedia filmu religijnego. 
Theology of Culture

and 7. selected films that only superficially use religious themes (death, afterlife, hell, etc.) but that many viewers consider religious. ${ }^{8}$

Based on the trends and tendencies of the latest films, the last three categories are of greatest interest here. The creators and viewers of these types of religious films pose questions about man's relationship with himself and others, as well as with the world and the cosmos. They also present metaphysical questions and transcend the rational worldview of science, which is unable to provide satisfactory answers to questions about the deepest essence and meaning of human existence.

Living in a "disenchanted world," " modern man often rejects transcendence and the sacred sphere in favor of a one-dimensional and empirical understanding of reality. Because of the postmodern revolt against metaphysics, many contemporary people consider faith insignificant and meaningless or, at best, completely private and separate from everyday existence. This does not mean, however, that questions about spirituality, especially those concerning the essence and meaning of life, no longer interest modern man. Lost in the rubble of the postmodern deconstruction of values and meanings, contemporary man still asks himself fundamental questions about the essence of being: Who am I? How should I live? What values should I have? What should I believe? The tragedy for modern man is the fact that he cannot find definitive answers to these questions. As a result, he is unstable and insecure; he feels lost and out of place in the society in which he lives; he feels alienated from himself and others; and he finds himself confused and searching in a hostile, unintelligible, technologized, and depersonalized world.

Carlos Reygadas presents such a world and throws ${ }^{10}$ such characters into his films. In his work, the Mexican director and contemporary creator of auteur cinema portrays how people feel lost in a culture of alienation, consumerism, rejection of tradition (including religious tradition) as a sphere that has lost all of its influence on forming the senses. At the same time, however, Reygadas (like the characters in his films) shifts from the real world to the immaterial, spiritual realm because, as Rafał Syska aptly points out, "he considers the search for transcendence to be man's natural, existential objective."11

\footnotetext{
$8 \quad$ M. Lis, ed., "Od redakcji," in Światowa encyklopedia, 8

$9 \quad$ M. Weber, Racjonalność, władza, odczarowanie (Poznań: 2004).

10 I use this word deliberately here because it recalls the deterministic fate of Reygadas' protagonists.

11 R. Syska, "Nostalgia za Tarkowskim. Kino Carlosa Reygadasa i Aleksandra Sokurowa," in Strefa filmu. Kino Andrieja Tarkowskiego, eds. I. A. Diaye and
} 
Reygadas' cinematic films tell about life and death, about love and its absence, about the protagonists' loss of faith and spiritual emptiness, and about their almost desperate search for transcendence. In the realistic and concrete world that he presents in his films, there are glimmers of another spiritual, immaterial world that exists in another space and a different time. On the periphery of the real world-the profane, the director creates a variety of unreal spheres and sacred realms that are invisible at first glance but crucial in order to understand the protagonists' actions and choices.

In his article "Redemption, Religion, and Reconsideration with Director Carlos Reygadas," 12 Scott Foundas asserts that the Mexican director's films are about characters who experience a dichotomy between what they believe-or, rather, what they have been taught to believe-and what they feel in the depths of their hearts. Foundas quotes Reygadas as agreeing with this statement and adds that he himself has a similar attitude toward faith. According to Reygadas this approach is a particular tension with which he has come to terms, but that still has a significant influence on his ambivalent view of the world. Reygadas emphasizes that feelings and values often evade each other and rarely coincide, and, when they do, it is only in some respects, and not in others. This is especially evident with regard to questions of faith and religion, which were once so important to the people of Mexico and which today have been forgotten, rejected, or treated at best very superficially as empty ritual passed down from parents and grandparents.

It would be wrong to define Carlos Reygadas' films as strictly religious, even though studies on his works connect them with faith, the sacred, and transcendence. ${ }^{13}$ The Mexican director's films contain a

M. Sokołowski (Toruń: 2013), 363

S. Foundas, "Redemption, Religion, and Reconsideration, with Director Carlos Reygadas,” January 7, 2009, The Village Voice, accessed September 21, 2016, www.villagevoice.com/2009/01/07/redemption-religion-and-reconsiderationwith-director-carlos-reygadas/.

13 See T. de Luca, "Carnal Spirituality: the Films of Carlos Reygadas," Sense of Cinema, July 2010, accessed November 12, 2020, https://www.sensesofcinema. com/2010/feature-articles/carnal-spirituality-the-films-of-carlos-reygadas-2/; M. O'Shea, “'Are You There God?' Secularization of Religious Narratives in Contemporary Cinema" (master's thesis, Carlton University, 2014), https://curve. carleton.ca/f5d52685-7e55-451d-b563-481c891d658e; A. Jablonska Zaborowska, "El campo simbólico-religioso en el cine mexicano actual," accessed October 17, 2020, https://dialnet.unirioja.es/servlet/articulo?codigo=5503118; J. Semley, "Director Paul Schrader and Cinema's Relationship with Religion," The Globe and Mail, March 30, 2017, https://www.theglobeandmail.com/arts/film/ 
hidden longing for the spiritual world, for man's lost union with the sacred, with nature (which is "divinized" in many works), with himself, and with his spirituality. The cinematic reality that Reygadas creates seems to be a distant trace of a higher order that man did not establish but that has an overwhelming influence on him.

\section{Semina Verbi in culture: the meeting of the Gospel with film art}

Post-conciliar theological documents on the relationship between the Christian faith and culture mention "semina Verbi" (seeds of the Word). ${ }^{14}$ This expression refers to the interaction between the Gospel and the cultures of different peoples. Proclaiming Christ's teaching, the Church embodies the Gospel within different cultural traditions and, at the same time, adopts what She considers good and beautiful from them. The encounter between the Gospel and culture takes place through semina Verbi, which are present in the cultural heritage of different peoples and societies. John Paul II used this metaphorical expression to convey that the Spirit sows the "seeds of the Word" that are present in various rites and cultures, thereby opening them to fullness (maturity) in Christ. ${ }^{15}$

Semina Verbi are elements of Christian truth present in non-Christian cultures as well as secular works of art. Bishop Robert Barron, among others, has been identifying such fragments of the Christian faith in postmodern popular culture. ${ }^{16}$ His essays on the art of film

paul-schrader-examines-cinemas-relationship-with-faith/article34497602/; A Piotrowska, "W stronę światła," Tygodnik Powszechny 21, no. 10 (2008), https:// www.tygodnikpowszechny.pl/w-strone-swiatla-132434; J. Atehortúa Arteaga, "Carlos Reygadas: Trascender la realidad para no ser esclavos de ella," Pajarera del Medio, December 14, 2016, https://pajareradelmedio.blogspot.com/2016/12/ carlos-reygadas-trascender-la-realidad.html.

See Second Vatican Council, Lumen Gentium [Dogmatic Constitution on the Church in the Modern World], https://www.vatican.va/archive/hist_councils/ ii_vatican_council/documents/vat-ii_const_19641121_lumen-gentium_en.html; Second Vatican Council, Ad Gentes [On the Mission Activity of the Church], https:/www.vatican.va/archive/hist_councils/ii_vatican_council/documents/ vat-ii_decree_19651207_ad-gentes_en.html; John Paul II, Redemptoris Missio [Encyclical on the Permanent Validity of the Church's Missionary Mandate], http://www.vatican.va/content/john-paul-ii/pl/encyclicals/documents/hf_jpii_enc_07121990_redemptoris-missio.html. John Paul II, Redemptoris Missio, 28. 
are particularly brilliant. Barron states that, with a little good will the Christian interpreter

... can see images of Jesus in Superman, Spider-Man, and Andy Dufresne; he can sense the play between divine love and divine mercy in the strong arms of Rooster Cogburn; he can hear an echo of Augustine's anthropology in the protagonist of Eat, Pray, Love; he can discern the powerful teaching on the danger of concupiscent desire in The Great Gatsby; he can sense a longing for the supernatural in The Exorcist and the Twilight series; he can pick up overtones of Jeremiah and Isaiah in Bob Dylan; he can hear the voice that spoke to Job out of the whirlwind in the Coen Brothers' A Serious Man; and he can appreciate one of the most textured presentations of Christian soteriology in Clint Eastwood's Gran Torino. [He then he adds:] Are any of these adequate presentations of the Word as such? Hardly. But are they all semina Verbi, seeds of the Word? Absolutely. ${ }^{17}$

Interestingly, in the context of Barron's considerations and analyses the question of artistic, written, and innovative works arises. It is not difficult to imagine that the superheroes of so-called "new adventure" feature films or cinematic genres such as science fiction, horror, crime, melodrama, or thriller are based to some degree on the Person of Jesus Christ, reproduce "attractive" biblical themes, or refer to the broadly understood idea of saving the world or redeeming sinful humanity. But, is it just as easy to find semina Verbi in artistic films with clear authorial strategic outlines, whose creators avoid pop-cultural themes and common and uniform interpretative associations? I think that it is definitely possible, but tracking down fragments of transcendence and traces of God in such works is more challenging (but all the more satisfying to researchers when they are found) than in mainstream cinema.

Perceiving semina Verbi as interpretative tropes seems to be an appealing approach to decipher how Carlos Reygadas' films have been received. The works of the Mexican director present a realistic, pragmatic vision of the world today and of the people lost in it. At the same time, however, they echo a longing for the sacred. These are stories about the intertwining of life and death, about love and its absence, about the protagonists' spiritual emptiness and their (sometimes desperate) desire to experience transcendence, even if it is secularized and devoid of contact with a personal God. 


\section{Transcendence in Reygadas' films as an act of transcending the moral fall of man}

Reygadas does not think very highly of the spiritual condition of modern man. In an interview about his film Post Tenebras Lux (2012), he stated:

Like my characters, we are all placed in similar situations in life. I will say, however, that Juan in Post Tenebras Lux is constantly dissatisfied, lonely, suffering. He treats everyone condescendingly; he complains and harangues and, in this way, destroys others and himself. He represents the status quo of people in the West today who are isolated from nature and others. ... In the finale, though, he has an epiphany, feels something for his wife, and mentions his childhood... Juan's children are filled with an intense love for their parents, nature, and their home, but they lose this when they are grown due to the western paradigm of the world, which prevents people from being happy. Mexico, like the rest of the world, is also dominated by this paradigm. Bloody narcotic wars do not arise because of poverty or political repression, but because of spiritual despair. ${ }^{18}$

In his films, Reygadas accurately diagnoses the modern world in which man-disconnected from nature and from God who creates itis confused and deeply frustrated. The Mexican director's characters are torn between the bodily sphere, requiring instant gratification, and the spiritual sphere, striving for a transcendence that is impossible to attain for different reasons. They long to overcome the fruitless difficulties of daily life and ascend to something higher, but they have lost the possibility to be spiritually renewed because they reject faith and deny God's existence. The religious ritual acts that they perform at times are empty to them, so these acts no longer have the strength to heal, which only increases the characters' frustration. The sacred and transcendent realm is, therefore, very inaccessible to the protagonists. And yet, in Reygadas' films this spiritual and transcendent realm exists and influences his characters' behavior. The viewer can observe it in the metaphysical fragments that appear in the world that Reygadas creates, in scenes that present the characters' behavior, and also in the landscapes that are saturated with meaning and serve as the symbolic backdrop of their actions. The spiritual and transcendent occur in the films as semina Verbi, bringing to mind the Word that proclaims the evangelical truth about man and his connection to the invisible God, who is not depicted on screen.

18 C. Reygadas, "Reżyser o filmie," accessed April 23, 2017, https://archiwum. stopklatka.pl/news/rezyser-o-filmie-16568. 
Sacred motifs appear in Reygadas' first feature film Japón (2002). The intriguing title of this work, the action of which does not even take place in the Land of the Rising Sun but in the harsh landscape of the interior of Mexico, refers to the East, which the director identifies with the sun, rebirth, and spirituality. The plot and themes, however, contradict this symbolism because the characters experience violence as well as physical and predominantly spiritual death. Shocking images appear in the very first scenes of the film: the main character twists off the head of a pigeon he has caught, the dark sounds of pigs squealing desperately as they are slaughtered can be heard, and a decomposing horse in a mountain landscape is shown. As the finale, a main character dies. The protagonist, whose name is not mentioned, arrives at a village hidden in the mountains where he intends to commit suicide for reasons unexplained by the plot.

And yet, the main character paradoxically experiences the possibility of spiritual rebirth and passage from death to life when he goes to the mountains to shoot himself. He hikes to the edge of a canyon in the pouring rain, which-in contrast to the protagonist's intention to commit suicide - clearly symbolizes purification, rebirth, and new life. In the following scenes, dark clouds hover above and then a decomposing corpse of a horse with a rotting member is shown a moment later. In the next scene, which takes place in a village at the foot of the mountains, a long veristic shot shows a stallion mounting a mare. The director juxtaposes images of life and death, the beginning and end of existence, which shock the viewers. This is the leitmotif of the entire film, which synchronistically opens up its ideational meaning toward metaphysical symbolism.

As the main character hikes closer to the edge of a cliff, he pulls out a gun. He does not shoot himself, but lifts the gun and points it above his head at the sky. As the camera follows this movement, it pans upward to show an impenetrable blanket of clouds and then stands still depicting a prolonged view of the sky. The clouds seem to be silent; if God exists somewhere behind the clouds, then He is very far away. And yet, the heavy rain within the scene conveys the clear symbolism of being washed and grace.

In the following scene, the main character leaves his weapon and walks away from the edge of the cliff. He falls to the ground and lays on his back next to the corpse of the horse as the aria "Erbarme dich Mein Gott" from Johann Sebastian Bach's Saint Matthew Passion plays in the background. The words of the aria are a supplication for God's mercy. The aerial shot shows the main character lying on the ground 
and then circles around him and the corpse of the horse, after which it pans back to a grey sky illuminated by a faint glow. The camera pulls away, showing the man recede into the ever-greater distance until he blends into the landscape and becomes as if a part of nature. From the aerial placement, the viewer can see trees, ravines, and rivers-in other words, the breathtaking beauty of the world. The light and silence manifest the sublime, a clear sign of transcendence. In the following shots, the viewer sees the protagonist descending to the bottom of the canyon to return to the village; he abandons his suicidal thoughts and begins an interior, spiritual journey from death to life.

The main character of Reygadas' film Battle in Heaven (2005) makes a similar journey up a mountain, at the peak of which he comes face to face with God. The protagonist, Marcos, hikes to the top of the mountain during a trip with his family and friends. His journey is symbolic; there is no rational explanation for why he abandons them during a picnic and hikes alone to the top of the mountain through thickets and thick fog that covers the landscape. The fog appears suddenly, and the viewer gets the impression that it prompts Marcos to climb to the top of a steep hill that towers above the surrounding area. In the Bible, clouds and fog are frequently used a symbol for the presence of God, who has descended to meet with man. The cloud hides God from man's sight, which symbolizes God's inaccessibility and transcendence. Both the Old and New Testaments contain this motif. For example, the column of cloud accompanied the Israelites during their escape from Egypt ${ }^{19}$ and covered the tent of meeting ${ }^{20}$ as well as the Temple of Jerusalem after the Ark of the Covenant was brought into it. ${ }^{21}$ In the New Testament, a cloud of light cast a shadow over Jesus during the Transfiguration on Mount Tabor. ${ }^{22}$ In addition, during Christ's ascension, "a cloud took [Jesus] from their sight," and all nations "will see the Son of Man coming upon the clouds of heaven with power and great glory" at the final judgment. ${ }^{23}$ In this way, the repeated symbol of clouds in Sacred Scripture call to mind events wherein God encounters man.

Additionally, the symbolism of the mountains is associated with expressions of the sacred. In his work Stowniku symboli [A Dictionary of

Exodus 13:21. These and the following passages come from the The New American Bible: Revised Edition (Charlotte, NC: Saint Benedict Press, 2010).

Ex 40,34-38.

1 Kgs 8:10-12.

Mat 17:5.

Ibid 24:30. 
Symbols], ${ }^{24}$ Juan Eduardo Cirlot states that a mountain, like the cross and the cosmic tree, mark the center of the world and a place where the sacred (hierophany) or divinity (theophany) are revealed. The hero climbs to the top of the mountain and - like the protagonist of Japón - looks into the abyss. There is no more fog at the peak. A long, static shot exposes the main character standing next to a large votive cross that is erected on the rock. As the camera pans, the viewers' gaze shifts away from the protagonist to the blue sky above him. Again, like in Japón, the camera's lens is pointed perpendicularly upward: the angle clearly connects the subjective point of view of the camera and the gaze of a man who has raised his face to the sky to see the Most High. The sun and the wind that blow at the peak symbolize God's presence. In the New Testament, the Hebrew word "ruah," means "wind, breath, spirit" and is synonymous with the Holy Spirit. Like Elijah on Mount Horeb, ${ }^{25}$ Marcos enters the sacred realm and encounters God face to face. Pious Jews covered their faces when they encountered God or even an angel, and, in covering his eyes with his hands, Marcos does the same.

Both scenes from Japón and Battle in Heaven do not show the main characters' encounter with God directly on screen. In both films, the viewers only see how the protagonists climb to the peak of the mountains, look up to the sky, then descend down the mountains, and their lives play out differently from this moment on. The symbolism is clear - all the more so because, as the films unfold, both protagonists want to go beyond their bare tedious, and dissatisfying existence and experience transcendence.

The desire for transcendence that gnaws at the films protagonists, which expresses their longing for metaphysicality, is a topical thread that runs throughout of all Reygadas' works, starting with his debut short films and ending with the most recent work Our Time (2018). This transcendence, however, is depicted onscreen in both a special and specific way. Rafał Syska characterizes it well, stating: "The metaphysical aspect of Reygadas' films derives from the two different forms in which his characters' experiences take place: either from an intense relationship with another human being and the intimacy of bodily contact that accompanies it, or from nearness to the natural world and a sense of severe pantheism." ${ }^{\prime 26}$

\footnotetext{
24 J. E. Cirlot, Słownik symboli, trans. I. Kania (Kraków: 2006), 141.

251 Kings 19:11-13.

26 R. Syska, "Nostalgia za Tarkowskim,” 363.
} 
Theology of Culture

The transcendence that Reygadas' characters experience is not so much metaphysical as biological, occurring within the bodily space of the world. It evokes the biological dimension of nature's rebirth, which occurs through cyclical death and re-flourishing. This type of experience leads the characters from passive stagnation and death to vitality and life.

The images of corporeality that open the characters to transcendence that appear in Reygadas' films can be associated with Yves Ledure's philosophical ideas. ${ }^{27}$ The French thinker claims that the human body naturally leads a person toward the transcendent, opening him to the Absolute. First, however, this transcendence leads downwards, not upwards, because corporeality focuses man's attention on the negative absolute - that is, on death. Then, through desire and longing, it leads him to the positive Absolute, which is God, Who is fullness of life. Traces of divinity are always found in human corporeality because God comes to man in the history of the world as an embodied being and reveals Himself to man through the incarnation. In Carlos Reygadas' films, man experiences the negative absolute not in death, but in his sexuality. Corporeality (and man's sexuality associated with it) enables him to move from negative to positive transcendence. In the sexual act, vital forces are activated along with the biology and dynamism that are dormant in them. These experiences end, however, with the triumph of corporeal life over the forces of destruction; therefore, although they draw the main characters upwards, they cease at the earthly level and do not reach the heavens.

The transcendence that Reygadas' characters experience consists in their self-transcendence and not in the transition from the physical sphere to the spiritual sphere. The mechanism, however, is similar; perhaps this is why the Mexican director juxtaposes sexual images against sacred stage props. In the film Japón, the character Ascen is often shown with images of Christ hanging in the background on the walls of her home and in the village church. A portrait of Jesus hangs above the bed on which she and the man have sexual intercourse. The elderly woman agrees to have sex with the man when he requests it in order to give her body as an offering that will redeem him, draw him out of his desire to die, and give him life. Ascen's participation in Sunday Mass underscores the sacrificial and redemptive character of her act. After giving the Sign of Peace to those around her who are participating in the celebration of the Eucharist, Ascen looks at the figure of the crucified Christ and smiles. In his interpretation of this

Y. Ledure, Transcendances: essai sur Dieu et le corps (Paris: 1989). 
scene, Rafal Syska notes that it is not the Blessed Virgin Mary, who is so popular and venerated by Mexican Catholics, who religiously inspires Ascen's actions, but rather Her Son:

Marian devotion leads to religious passivity and a purely emotional experience. Meanwhile, Ascen, who is often portrayed against the background of images of Christ, is associated with active redemption that is accomplished through the sacrifice of one's own body. For the protagonist, the sexual proposition that he makes to the woman was, therefore, a decision to live, and Ascen's [acceptance of this proposal is] a Christian act of redemption..$^{28}$

For the reasons mentioned above, Salvador Velazco claims that Reygadas' film can be interpreted as a biblical parable that calls to mind the fundamental truths of the Christian faith because Ascen, like Jesus, dies to save the life and soul of another person. ${ }^{29}$

In the film Battle in Heaven, the act of sexual intercourse between Marcos and his wife is juxtaposed against a reproduction of Antonello de Messina's painting The Dead Christ Supported by an Angel that hangs on the wall. From Jesus' pierced side flow streams of blood. However, the image of the Savior, which no longer has a sacred influence on the characters, has become a meaningless decoration in the bedroom. At some point, the spouses lost a sense of living faith—or, rather, they likely never had it. Traditional expressions of religiosity that have been cultivated in their lives (the wife proposes to her husband that they go on a pilgrimage to the shrine of Our Lady of Guadalupe as reparation for the kidnapping of her cousin's infant for ransom) have become empty gestures and rituals from the past just like their selfish sexual spectacle from which the marital bond, love, and support have long since evaporated.

Although the main character of Battle in Heaven-Marcos-obstinately strives for transcendence throughout the film, his efforts are desperate and fruitless because traditional values and personal faith are no longer meaningful to him. Having experienced the kidnapping of a child for ransom and blaming himself for inadvertently causing it, the protagonist longs for redemption while simultaneously rejecting the path that the Christian religion proposes because it seems barren and empty to him. Instead of having faith, Marcos chooses his own rituals (e.g., sex with his boss' daughter, Anna, who he desires

28 R. Syska, "Nostalgia za Tarkowskim,” 362-363.

29 S. Velazco, "Eros y Tanatos en Japón de Carlos Reygadas," in El ojo que piensa. Revista de cine iberoamericano, no. 4 (2011), accessed March 12, 2016, http:// www.elojoquepiensa.cucsh.udg.mx/index.php/elojoquepiensa/article/view/63. 
and considers unattainable due to social and class barriers, placing Mexico's national flag on a mast, or making a pilgrimage to a sanctuary while wearing a jute sack on his head), which ultimately leads to his defeat. Within the context of the protagonist's desire to experience transcendence, Piotr Więcek interestingly points out Marcos' loss of visual acuity is depicted onscreen: ${ }^{30}$ Marcos loses his glasses in the subway and, from that moment forward, moves uncertainly but with greater inner determination. Więcek rightly comments:

Unable to see the surrounding world clearly, the protagonist can concentrate on the tiny movements of his soul or, put differently, he can perceive a second transcendent layer of reality. In these moments of "second sight" he does a variety of irrational things; he decides to admit his guilt to Anna, climb the holy mountain, and crawl on his knees to the temple. He also engages in ritual sex, which (in Marcos' opinion) transcends social barriers, which enables him to 'transcend himself.' In the final analysis, however, every ritual proves to be empty because Marcos, who is torn between two worlds, does not belong to either of them-neither to the traditional world filled with religiosity, because it means nothing to him since it does not bring about his purification, nor to the modern bourgeois world to which Anna belongs but to which he has no access because he belongs to a different class. ${ }^{31}$

The main character of Battle in Heaven (note that the film's title also clearly has a biblical connotation) loses his struggle to overcome the barriers that hinder him. In Marcos' case, as Więcek rightly highlights, his actions are performed in vain and condemn him to failure:

...every ritual, whether sexual or religious, means nothing anymore; it has become only an empty form or, even more, the manifestation of an institution's power (flag, pilgrimage) over the individual, of man over woman. A dead ritual that has lost its power to renew and has no effect on [a person's] individual experience only increases frustration and alienation. This, Reygadas seems to say, is the experience of the contemporary Mexican. ${ }^{32}$

Reygadas also reminds his audience, however, that this is also the experience of modern man in general. The widespread culture of ubiquitous consumerism and the desire to be someone of importance without competence, which are artificially driven and promoted by advertising, do not satisfy or fulfill man but only increase his hunger

30 P. Więcek, "Bitwa w niebie, reż. Carlos Reygadas," Nowe Horyzonty, accessed November 20, 2014, https://www.nowehoryzonty.pl/artykul.do?id=1307.

31

Ibid.

32 Ibid. 
for ever-new, unrivaled experiences. The discovery or rediscovery of a forgotten spiritual sphere within one's self could satisfy this longing, but often Reygadas' protagonists no longer know how to achieve this, as is evidenced in his most recent films: Post Tenebras Lux (2012) and Our Time (2018). The protagonists of these films are unable to experience transcendence through the movement from death to the vitality of life, even in a bodily sense, and the sexual aspect of their lives is a clear sign of their destruction and decline: the main character of Post Tenebras Lux is addicted to pornography and is unable to please his wife, while the protagonist of Our Time changes from a tolerant husband into a jealous pimp.

In another of Reygadas' films, Silent Light (2007), transcendence that leads upwards to God and is achieved through overcoming the biological sphere of corporeality and death in a morally scandalous manner is depicted not in a sex scene, but rather in a resurrection scene. In this film, Reygadas presents the main character's resurrection as something completely natural; the current order of existence in the Mennonite community remains entirely undisturbed after the death and resurrection of a woman. After dying, Esther returns to life simply as a natural turn of events: no one is surprised, and it is as if her sudden death and the subsequent miraculous return to life are the logical culmination of the events that precede them. Wonder, as Reygadas states when commenting on his film, is a natural element of the world that occurs often and yet almost always goes unnoticed. In an interview with Paweł Urbanik, Carlos Reygadas said:

Every day everything is ceremonial, mysterious, and marvelous; an inexplicable miracle is something ordinary. I think that's what life is like: It is full of miracles that we do not see probably because something arouses our interest only when it is scientifically difficult to explain. I wanted to blur the line between miracle and life and show life as a miracle in itself. That is why the film's opening scene of dawn, children in the water, or simply a car in movement are as significant to the story as the closing scene that is filled with wonder but treated as ordinary. ${ }^{33}$

The transcendence that leads the protagonists of Silent Light to the sacred and transforms their struggle and suffering into an encounter with God's mercy comes from everyday life, from the country landscape saturated in a still, omnipresent, unearthly light, which is an obvious sign of the presence of the Most High. It is also a consequence of the choices of the protagonists, who have mutual empathy for each

$33 \quad$ Paweł Urbanik, "Zycie Jest Cudem," Polskie Radio PL, accessed October 27, 2019, https://www.polskieradio.pl/24/286/Artykul/167214,Zycie-jest-cudem. 
Theology of Culture other. In the film, the director successfully tells about the power and essence of true love in the Christian sense of renouncing oneself for the good of the beloved. Because of such love, the sinful love triangle and affair with his neighbor in which Johan had become entangled is broken. True love, which Reygadas talks about in his film, is a miracle; it suspends the order of nature and is able to turn back time, thus restoring the world's balance as well as its cosmic and divine order. In both Japón and Silent Light, merciful caritas, known as the willing sacrifice of one's self for others and their good, is the choice that saves the protagonists.

Reygadas based his film Silent Light on Carl Theodor Dreyer's famous work Ordet (The Word, 1955). Reygadas and Dreyer's films are united by the final scene, in which the deceased protagonist is miraculously and inexplicably resurrected. In Ordet, Johannes brings his sister Inger back to life through a prayer and petition to Jesus and through Inger's little daughter's trust-filled faith. Johannes, who everyone considers mentally ill, represents indomitable faith that moves mountains. In Silent Light, Marianne, who similarly believes in the possibility of redeeming forgiveness through the transformation of eros into merciful caritas, restores life to the wife of her recent lover with a kiss.

In Dreyer's work, Johannes' bitter observation, which he expresses when he asks those gathered at the vigil why not a single one of them really believes, conveys the film's credo. The question seems strange when considered in light of the entire plot, during which issues pertaining to faith in Jesus and disputes about the essence of God often arise. In Reygadas' film, on the other hand, the Mennonites rarely talk about God, but their faith seems deep, sincere, and connected directly to their everyday lives. But even the deepest faith, adherence to strict moral principles, and knowledge of the Bible are not able to protect the protagonists from what is human and sinful. The final scene depicting the resurrection of the protagonist of Silent Light's does not provide a clear answer to the question of whether God or human love, compassion, and forgiveness bring about supernatural intervention. Both possibilities are not mutually exclusive and could have occurred simultaneously. Reygadas does not depict God acting directly, but, by interpreting Esther's resurrection from the dead in the spirit of the Christian parable of a miracle performed through the power of merciful love, he clearly seems to suggest it. 


\section{The presented world and its space-time components of Reygadas' films as an invitation to the viewer to contemplate}

The world presented in Silent Light - the cinematic planes of space and time-also seems to evoke subtly but purposefully a supernatural order. The film begins and ends by bringing together the events depicted in it, drawing forth the metaphysical order hidden in them. The long, static shot that begins the film captures dawn, while the parallel final shot shows the descent of twilight. The film's prologue presents contemplative images of a starry sky that slowly brightens in the east. The camera, which is pointed toward the firmament, clearly suggests God's presence - a "silent light" — that makes everyday, ordinary reality holy and accompanies the protagonists in all of their actions. The image of the sun emerging on the horizon is accompanied by the sounds of night and the approaching dawn: crickets chirping, dogs barking, cattle mooing, birds chirping, and wind blowing through the trees. The opening scene of the film seems to suggest the biblical account of the creation of the world, especially the verses that speak about God separating the darkness from the light. ${ }^{34}$ Maria Kornatowska describes things in this way:

The film's framework-the vision of the star-studded sky-evokes Kant and suggests other, including metaphysical, meanings. Conflict of conscience and passion are the essence of Silent Light. Here, however, passion has less to do with the body and more to do with the soul. It is an expression of the human need to transcend boundaries and limitations. It is a force that can destroy, kill, and restore life. This story of amorous passion, death, and even resurrection has a deeply religious meaning. ${ }^{35}$

The light that divinizes the cinematic reality also plays an important role in Reygadas' work, as the title of his film Post Tenebras Lux suggests. This title is taken from a fragment from the Book of Job in the Latin Vulgate: "Post tenebras spero lucem" "Light comes after the darkness; I hope for the light"). The prologue of this film includes a scene that symbolically introduces the audience to the mood and meaning of the film's different threads. In the work's initial shots the viewer sees a little girl running around a country playground with dogs

34 "Then God said: Let there be light, and there was light. God saw that the light was good. God then separated the light from the darkness. God called the light 'day,' and the darkness he called 'night'” (Gen1:3-5). 
Theology of Culture

that are chasing cows. The child is cheerful, jumps through puddles, and calls out to the animals. Slowly, however, the landscape darkens under the impending clouds and evening twilight. The sounds of an approaching storm can be heard as the girl calls her mother who does not come. Slowly, imperceptibly, but clearly horror approaches; the cows are restless and the dogs are aggressive in the darkness. Lightning lights up the sky, animals look ominous like demonic creatures, and the title of the film appears against the backdrop of a landscape that emerges fitfully from the darkness.

In the next scene, a demon comes to the house where everyone is sleeping. The figure is naked, which reveals that he is male (this is significant because the male characters in the film represent demonic attitudes). He also wears a dog muzzle and has a goatee, horns, hooves, and a nervously-moving tail. He carries a mysterious suitcase. He walks quietly but confidently, as if he knows precisely why and to who he is paying his visit. The juxtaposition of these two images: an innocent, joyful child and an emaciated, grotesque, neon-red glowing demonic figure suggests the film's main theme: the entanglement of purity and villay, innocence and sin, good and evil. The subsequent scenes are not arranged chronologically; they jump freely from one stage of the characters' lives to another. The protagonists' fantasies, dreams, and memories are as real and significant as their actual lives, and both are depicted on the same plane. Time jumps, flashbacks, and futurospections disturb the narrative order and time frame of the plot. This perhaps suggests that the cinematic timeline and characters are determined not by chronos but by kairos.

The ancient Greek word "kairos" means a turning point or moment when a person is forced to make a decisive decision that will completely change his life as he has known it. In theology, the word kairos means a definitive moment in history when God performs a saving action. It is also a time of grace that is given to man to man so that he can seize his relationship with God. Man can take advantage of God's proposal, or he can bypass, ignore, or reject this opportunity. This is generally what happens to Reygadas' characters: they are unable to be open to the breath of transcendence and go beyond their own frustrations, emptiness, and loneliness. The protagonist of Post Tenebras Lux is the most obvious example of this, which makes the title of the film perversely ironic. Perhaps, however, the light that follows the darkness will transform the lives of the main character's children insofar as they are able to remain pure of heart as well as sensitive and empathetic toward others. 
In fact, empathy is what saves the main character of Silent Light, Marianne. She does not waste the kairos that is given to her-a time reordered according to the divine that had been disrupted beforehand by her sinful affair. Immediately after the opening scene begins, Marianne is seen climbing onto a chair to stop the pendulum of the clock hanging on the wall. The clock that the protagonist stops is a clear reference to Dreyer's film Ordet. In the Danish film, however, the stopping and restarting the clock after Inger's resurrection reflects a traditional European cultural practice of stopping a clock, the ticking of which measured the hours a person's earthly life, after a person has died to signify that his earthly life has ended. It was commonly believed that if the clock is not stopped, then the ticking would disturb the deceased unnecessarily and call him back to earth. In Reygadas' film, however, the clock is stopped at the beginning of the story, rather than at the moment of Esther's death. In this way, the clock plays a different role and symbolizes that time in the film and the main character's choices are ordered not by chronos, but by kairos, which enables Marianne to undo the effects of her sinful actions. Marianne takes advantage of this time of grace, which gives her the opportunity to reverse choices that she made that were contrary to God's plan. By having an affair with his neighbor, Johan breaks taboo and rejects religion, the Decalogue, the customs of his community, and his family. When his wife dies, it seems like chance has come to his aid and relieved him of his duties as the head of the family. Johan, however, does not feel free; on the contrary, he falls into despair as he becomes aware of the sin that he has committed and its consequences. He misinterprets the signs from heaven and wastes his time of grace. Marianne restores harmony to his ruined world by being aware of God's prompting. Thanks to her sacrifice, the characters experience a miracle. Anita Piotrowska says the following about the end of the dramatic story:

The unstable order was completely destroyed with one blow. Only on these ruins do the characters experience a miracle-a grace given only to those who believe. Armed with the cold and almost motionless eye of the camera, Reygadas films this purifying, luminous finale as if one of the protagonists - a member of the Mennonite community, someone who believes implicitly —were standing behind the camera. ${ }^{36}$

Carlos Reygadas' films are examples of neomodernist and slow cinematic styles. In accordance with the principles of slow cinema, Reygadas uses specific stylistic and narrative elements to introduce

$36 \quad$ A. Piotrowska, "W stronę światła," Tygodnik Powszechny, accessed October 30, 2019, https://www.tygodnikpowszechny.pl/w-strone-swiatla-132434. 
his audience to a specific state of contemplation. Contemplation is the art of mindful, pure vision; it can be described as a simple sensory perception of reality as it is. Reygadas presents the sacral dimension of cinematic space and time in his films through long, aesthetically beautiful, slow-motion shots of the setting in order enable his audience to "absorb" these extraordinarily impactful images through their perception and senses. As a result, the viewers experience a kind of transcendence similar to what occurs during mystical contemplation, in which the contemplative "I" identifies itself with the object contemplated. But is modern man, who rejects mystical experience in favor of a rational and cold view of reality, really able to experience the contemplation that would unite him with God and the world? Even more, is it possible to invite others to such contemplation through the plot of a film, or is this just a substitute for contemplation? Joanna Gruca describes the feelings of the viewers of Reygadas' films as follows:

What does one do in a situation where, after the postmodern revolt against Western European metaphysics of presence that is based on dualisms, the religious consciousness of modern times has negated the categorical opposition of concepts and, thereby, deprived them of the meaning that ennobles them? In a world without God, in which man who follows the burned-out out reflex of "divinity" in nature, the ever-increasing perspective of non-presence continually dominates, and questions concerning man's condition in the fragility of time are processual. They point to variability, fluctuation, and transgressing the boundaries of rational cognition in favor of contemplation, of bringing one into a state of hypnotic meditative feeling of that which "occurs" without a specific cause, while bypassing the expected effect. ${ }^{37}$

In this case, the reference to the sacred contained in the cinematic image occurs as a special, unexpected, immeasurable, and symbolic element that points to the divine realm of God Who transcends it. The film's ability to lead the audience to experience numinosum is a manifestation of the sacred in art. ${ }^{38}$ The sacred and the images of transcendence that lead to it are semina Verbi, the hidden seeds of truth contained in God's Word, which proclaims the Good News to man.

In his work Seeds of the Word: Finding God in the Culture, Robert Barron recalls his professor Monsignor Robert Sokolowski who once told him that the "integrated icon of Christian doctrine... exploded at

37 J. Gruca, "Post tenebras lux, reż. Carlos Reygadas, a po światłości, śmierć," Magazyn Filmowy Cinerama, accessed March 28, 2018, http://mfcinerama.pl/ post-tenebras-lux-rez-carlos-reygadas-a-swiatlosci-smierc/.

38 Władysław Stróżewski writes in this way about the sacred in art in "O możliwości sacrum w sztuce,” in Wokót piękna. Szkice z estetyki (Warszawa: 2002), 215-217. 
the time of the Reformation and the Enlightenment, and its charred and distorted fragments have landed here and there, littering the contemporary cultural environment." ${ }^{39}$ We can find these charred remains in many places insofar as we track them down and perceive them. Such burnt fragments of the truths of the faith and the Gospel appear often in Carlos Reygadas' films, which recall and evoke the realm of the sacred, thereby inviting the viewers to meditate and contemplate. Whether the viewers perceive Imago Dei in Reygadas' cinematic images and recovered depictions or only the remains of religious traditions that are empty and have lost their ability to have any real influence in today's world depends on whether the they are paying attention and able.

\section{Bibliography}

1. Atehortúa, Arteaga J. "Carlos Reygadas: Trascender la realidad para no ser esclavos de ella." Pajarera del Medio. Accessed December 14, 2020. https://pajareradelmedio.blogspot.com/2016/12/carlos-reygadastrascender-la-realidad.html.

2. Barron, R. Seeds of the Word: Finding God in the Culture. Des Plaines: Word on Fire, 2019. Kindle E-book.

3. Blask religii. Media $w$ poszukiwaniu sacrum i autorytetów. Edited by M. Sokołowski. Toruń: 2016.

4. Cirlot, J. E. Stownik symboli. Translated by I. Kania. Kraków: 2006.

5. Citko, K. "Bitwa w niebie, czyli marzenia meksykańskiego szofera." In Kultura pragnień $i$ horyzonty neoliberalizmu, edited by W. J. Burszta and A. Kisielewski. Poznań: 2015.

6. Citko, K. “'Sacrum i profanum' w kinie Carlosa Reygadasa." In Blask religii. Media $w$ poszukiwaniu sacrum $i$ autorytetów, edited by M. Sokołowski. Torun: 2016

7. De Luca, T. "Carnal Spirituality: the Films of Carlos Reygadas." Sense of Cinema, July 2010. Accessed November 12, 2020. https://www.sensesofcinema.com/2010/feature-articles/carnal-spirituality-the-films-of-carlosreygadas $-2 /$.

8. Foundas, S. "Redemption, Religion, and Reconsideration, with Director Carlos Reygadas." The Village Voice, January 7, 2009. Accessed September 21, 2016. www.villagevoice.com/2009/01/07/redemption-religion-andreconsideration-with-director-carlos-reygadas/.

9. Gruca, J. "Post tenebras lux, reż. Carlos Reygadas, a po światłości, śmierć." Magazyn Filmowy Cinerama. Accessed March 28, 2018. http://mfcinerama. $\mathrm{pl} /$ post-tenebras-lux-rez-carlos-reygadas-a-swiatlosci-smierc/.

10. Jablonska-Zaborowska, A. "El campo simbólico-religioso en el cine mexicano actual. The symbolic religious field in the current Mexican

39 R. Barron, Seeds of the Word, e-book. 
Theology of Culture

cinema." Accessed October 17, 2020. https://dialnet.unirioja.es/servlet/ articulo? codigo $=5503118$.

11. Kempna-Pieniążek, M. Formuty duchowości w kinie najnowszym. Katowice: 2013

12. Kłys, T. "Filmy (nie)religijne." In Między stowem a obrazem, edited by M. Jakubowska, T. Kłys, and B. Stolarska. Kraków: 2005

13. Kolasińska, I. "Film biblijny." In Wokót kina gatunków, edited by K. Loska. Kraków: 2001

14. Kornatowska, M. “Ciche światto.” Kino, no. 10 (2008).

15. Marczak, M. Poetyka filmu religijnego. Kraków: 2000

16. Piotrowska, A. "W stronę światła." Tygodnik Powszechny, October 21, 2008. Accessed October 30, 2019. https://www.tygodnikpowszechny.pl/w-strone-swiatla-132434.

17. Poszukiwanie i degradowanie sacrum $w$ kinie. Edited by W. Przylipiak and K. Kornacki. Gdańsk: 2002

18. Reygadas, C. "Reżyser o filmie.” Accessed April 23, 2017. https://archiwum. stopklatka.pl/news/rezyser-o-filmie-16568.

19. Sacrum w kinie dekadę później. Szkice, eseje, rozprawy. Edited by S. J. Konefał, W. Zelent, and K. Kornacki. Gdańsk: 2013.

20. Sokołowski, M. Kościót, kino, sacrum. W poszukiwaniu definicji filmów o tematyce religijnej. Olsztyn: 2002

21. Syska, R. "Nostalgia za Tarkowskim. Kino Carlosa Reygadasa i Aleksandra Sokurowa." In Strefa filmu. Kino Andrieja Tarkowskiego, edited by I. A. Diaye and M. Sokołowski. Toruń: 2013.

22. Światowa encyklopedia filmu religijnego. Edited by M. Lis and A. Garbicz. Kraków: 2007.

23. The New American Bible: Revised Edition. Charlotte, NC: St. Benedict Press, 2010.

24. Velazco, S. "Eros y Tanatos en 'Japón' de Carlos Reygadas.” El ojo que piensa. Revista de cine iberoamericano, no. 4 (2011). Accessed March 12, 2016. http://www.elojoquepiensa.cucsh.udg.mx/index.php/elojoquepiensa/ article/view/63.

25. Więcek, P. "Bitwa w niebie, reż. Carlos Reygadas." Nowe Horyzonty. Accessed November 20, 2014. https://www.nowehoryzonty.pl/artykul. do? id $=1307$. 